\title{
LEGISLATIVNÍ RÁMEC ROKU 2012 PRO PODNIKÁNÍ V OBLASTI OBNOVITELNÝCH ZDROJŮ ENERGIE
}

\author{
Nina Pawliczková, Adam Pawliczek
}

\section{Klíčová slova:}

Obnovitelné zdroje energie (OZE), podnikání, udržitelná ekonomika, legislativní regulace, technologie

\section{Key words:}

Renewable Energy Sources (RES), Entrepreneurship, Sustainable economy, Legal control, Technology

\begin{abstract}
Abstrakt
Příspěvek se zabývá legislativními podmínkami aktuálními v roce 2012 pro podnikání v oblasti obnovitelných zdrojů energie (OZE) v České republice. Zmiňuje principy politiky OZE v ČR vycházející ze směrnic EU a podstatné právní úpravy související s podnikáním v OZE. V dalších odstavcích jsou charakterizovány specifické podmínky pro podnikání v oblastech využití větrné energie, energie vodních toků, tepelné energie zemského pláště, podzemních vod a energie prostředí, biomasy a sluneční energie. Závěr krátce shrnuje perspektivy podnikání v OZE v blízké budoucnosti jako významnou aktivitu udržitelné ekonomiky.
\end{abstract}

\begin{abstract}
Presented item deals with legal conditions for entrepreneurship in the branch of renewable energy sources (RES), valid in the year 2012 in the Czech Republic. There are mentioned policies of RES in CR rising from EU directives and important legal regulations concerning entrepreneurship in RES. Next paragraphs characterize specific conditions for entrepreneurship in utilization of wind energy, hydropower, geothermal energy, biomass and solar power. The conclusion shortly summarizes perspectives of entrepreneurship in RES in near future as a basic activity of sustainable economy.
\end{abstract}

\section{Úvod}

České právo zná více právních definic obnovitelných zdrojů energie („OZE“). Jednou z nejstarších představuje $\S 7$ odst. 2 zákona č. 17/1992 Sb. o životním prostředí: „Obnovitelné př́rodní zdroje mají schopnost se při postupném spotřebovávání částečně nebo úplně obnovovat, a to samy nebo za přspéní člověka. "Shodná je definice OZE, kterou uvádí § 2 odst. 1 zákona č. 180/2005 o podpoře výroby elektřiny z obnovitelných zdrojů energie (,Zákon o podpoře OZE“) a § 31 odst. 1 zákona č. 458/2000 Sb., o podmínkách podnikání a o výkonu státní správy v energetických odvětvích a o změně některých zákonů (,Energetický zákon“): „Obnovitelnými zdroji se rozumí obnovitelné nefosilní přirodní zdroje energie, jimiž jsou energie větru, energie slunečního záření, geotermální energie, energie vody, energie půdy, energie vzduchu, energie biomasy, energie skládkového plynu, energie kalového plynu a energie bioplynu.“. Definice obsažená v Energetickém zákoně byla zrušena.

Smysl a cíl právní úpravy využívání OZE spočívá v ,podpoře stálého rưstu ve využívání těchto zdrojü“. OZE patří mezi nástroje energetické politiky a politiky ochrany životního prostředí. Tyto skutečnosti zakládají nutnost existence závazné právní úpravy a jejího vývoje. 
Z hlediska podnikání v oblasti OZE, podle zákonů a prováděcích předpisů, mají mít „investice vložené do OZE zaručenou návratnost, a to po určitou dobu, kdy by mély prokázat svou konkurenceschopnost vůči ostatním neobnovitelným zdrojům" [1].

\section{Právní úprava OZE}

Oblast OZE je upravena především zákony, vyhláškami Ministerstva průmyslu a obchodu a vyhláškami a cenovými rozhodnutími Energetického regulačního úřadu („ERU゙“) [9]. Česká právní úprava vychází ze směrnic Evropské unie, jako povinná transpozice směrnic. Jedná se o Směrnici Evropského parlamentu a Rady 2001/77/ES ze dne 27. záŕí 2001 o podpoře elektřiny vyrobené $\mathrm{z}$ obnovitelných zdrojů energie na vnitřním trhu s elektřinou, která vstoupila v platnost dne 27. 10. 2001. Směrnice zavazuje členské státy k dosažení podílu elektrriny vyrobené z OZE do roku 2010 tak, aby byl podíl elektřiny vyrobené z OZE na celkové spotřebě elektřiny ve Společenství ve výši $22,1 \%$. ČR bylo určeno, aby do roku 2010 z OZE zajistila $8 \%$ hrubé domácí spotřeby elektrriny. Směrnice měla být do české legislativy implementována, na základě Smlouvy o přistoupení a souvisejících přístupových akti̊, které byly zveřejněné v Úředním věstníku Evropské unie č. L 236 dne 23. 9. 2003, zároveň se vstupem ČR do EU. Toto, s mírným zpožděním, realizoval Zákon o podpoře OZE. Znění tohoto zákona předpokládá vydání několika vyhlášek. Většina $\mathrm{z}$ nich byla připravena, projednána a následně vstoupila $v$ platnost ihned po přijetí Zákona o podpoře OZE. Jedná se o vyhlášku ERÚ č. 475/2005 Sb., kterou se provádějí některá ustanovení zákona o podpoře využívání obnovitelných zdrojů, vyhlášku Ministerstva životního prostředí č. 482/2005 Sb., o stanovení druhů, způsobů využití a parametrů biomasy při podpoře výroby elektřiny $\mathrm{z}$ biomasy a vyhlášku ERÚ č. 502/2005 Sb., o stanovení způsobu vykazování množství elektřiny při společném spalování biomasy a neobnovitelného zdroje, vyhlášku Ministerstva průmyslu a obchodu č. 343/2008 Sb., kterou se stanoví vzor žádosti o vydání záruky původu elektrriny z OZE a vzor záruky původu elektřiny z OZE a 140/2009 Sb., O způsobu regulace cen $v$ energetických odvětvích a postupech pro regulaci cen.

Evropská komise navrhla pro oblast energetiky a ochrany klimatu v rámci Klimatickoenergetického balíčku zvýšení podílu OZE na celkové energetické spotřebě o $20 \%$ do roku 2020. K realizaci tohoto návrhu vstoupila v platnost dne 25. 6. 2009 Směrnice Evropského parlamentu a Rady 2009/28/ES ze o podpoře využívání energie z obnovitelných zdrojů a o změně a následném zrušení směrnic 2001/77/ES a 2003/30/ES, zveřejněna v Úředním věstníku Evropské unie dne 5. 6. 2009 na č. L 140. Pro Českou republiku byl stanoven závazný cíl podílu energie z OZE na hrubé konečné spotřebě energie ČR v roce 2020 ve výši $13 \%$. Směrnice 2001/77/ES je touto směrnicí postupně zrušena, vybraná ustanovení od 1. dubna 2010 a celá směrnice s účinností od 1 . ledna 2012.

Tzv. Akční plán pro energii z obnovitelných zdrojů konkretizuje realizaci závazků vyplývajících ze směrnice. Uvádí strategie, zohledňuje dopady, předvídá opatření, která bude nutné přijmout. Vzor Národního akčního plánu byl přijat Komisí dne 30. 6. 2009 a zveřejněn v Úředním věstníku Evropské unie č. L 182. Směrnice stanovila povinnost členských států předložit své Národní akční plány Komisi do dne 30. 6. 2010 a následně také budou probíhat kontroly jeho plnění. Z podnikatelského hlediska je důležitý požadavek obou uvedených směrnic na změnu správních postupů schvalování a povolování zařízení na výrobu elektřiny, tepla nebo chlazení z OZE. Právní předpisy a administrativa by měla být přiměřená, objektivní a transparentní. Směrnice počítá s další podporou OZE po roce 2020, odpovídající plán by měla prezentovat $\mathrm{v}$ roce 2018 . 
Obrázek č. 1 zobrazuje podíl OZE na pokrytí prríslušné hrubé sektorové poptávky - tepelná energie, energie pro dopravu (biopaliva) a elektrická energie - po energii v ČR a sousedních zemích Slovensko, Polsko, Rakousko a Německo, včetně vyznačení cíle podílu OZE na celkové energetické spotřebě v roce 2020. Nejvyšší podíl OZE zaznamenává Rakousko, kde převažuje výroba elektřiny z velkých vodních elektráren a biomasy k vytápění.

\section{Obrázek č. 1: Srovnání podílu OZE na pokrytí př́íslušné hrubé sektorové poptávky po energii v ČR a sousedních zemích.} y: Podíl OZE na pokrytí př́slušné hrubé sektorové poptávky po energii (\%)

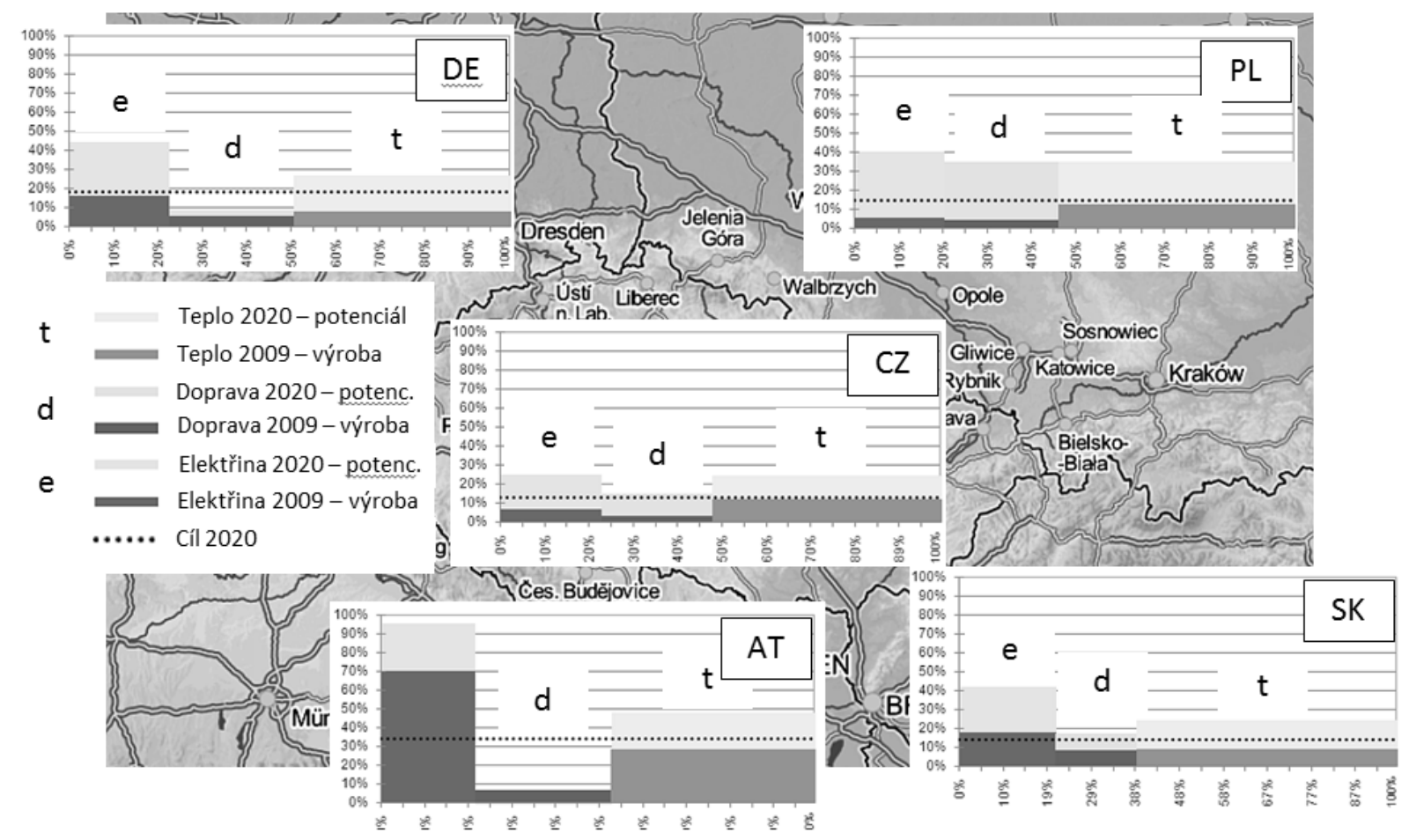

$\mathrm{x}$ : Podíl celkové spotřeby sektoru na konečné celkové spotřebě energie (\%)

Zdroj: RE-SHAPING Project [11].

\section{Podnikání v OZE}

Česká republika je tradičně orientovaná na uhlí a jadernou energii, ani poloha naší země nepřispívá $\mathrm{k}$ lákavosti využívání OZE. Např. průměrný počet hodin solárního svitu (bez oblačnosti) se v ČR pohybuje v rozmezí 1400h/rok až 1700h/rok. [3] Mezi hlavní možnosti podnikání v OZE patří využívání energie vodních toků v malých vodních elektrárnách; využívání energie větru; využívání sluneční energie v aktivních solárních systémech, pasivní solární architektuře a fotovoltaických systémech; využívání geotermální energie a energie prostředí převážně s použitím tepelných čerpadel; využívání pevné biomasy, kapalných biopaliv a bioplynu [5].

Základním zákonem upravujícím aktivity v energetických odvětvích je Energetický zákon. Předmětem podnikání se zde rozumí přenos, distribuce a obchod s elektřinou; výroba, přeprava, distribuce, uskladňování a obchod s plynem; výroba a rozvod tepelné energie. Výrobci elektřiny z OZE mají, pokud o to požádají a pokud splňují podmínky stanovené prováděcím právním předpisem, podmínky obsažené v Pravidlech provozování přenosové soustavy a Pravidlech provozování distribuční soustavy, právo $\mathrm{k}$ přednostnímu připojení svého zdroje elektřiny k přenosové soustavě nebo distribučním soustavám za účelem přenosu nebo distribuce. 
Právo podnikat v OZE náleží, za podmínek stanovených Energetickým zákonem, fyzické či právnické osobě, pouze na základě státního souhlasu, kterým je licence udělená ERÚ [5]. Právní úprava žádosti o licence a rozhodování o nich je obsažena jak v Energetickém zákoně, tak i ve vyhláškách ERÚ (426/2005 Sb., 363/2007 Sb., 358/2009 Sb.), v neposlední řadě zákon č. 500/2004 Sb. Správní řád, který se uplatní pro proces vyřizování žádosti o licenci.

Žádost o licenci se podává na formuláři, který je $\mathrm{k}$ dispozici v elektronické formě či tišstěný. Licence je udělována nejdéle na dobu 25 let, přičemž sám žadatel v žádosti uvádí požadovanou dobu, na kterou má být licence udělena, spolu s datem zahájení činnosti. Oprávnění k provozování licencované činnosti vznikne nejdříve dnem právní moci rozhodnutí o udělení licence (po uplynutí 15 dní pro podání rozkladu, anebo dříve v prrípadě vzdání se práva pro podání opravného prostředku). Určité instituce (např. finanční úřad, rejstř́kový soud) mohou požadovat vyznačení právní moci na rozhodnutí o udělení licence.

Mezi obecné předpoklady žadatele o licenci patři dosažení věku 18 let, úplná způsobilost $\mathrm{k}$ právním úkonům, bezúhonnost (od 1. 7. 2008 nemá žadatel o licenci povinnost dokládat bezúhonnost výpisem z Rejstříku trestů, namísto toho je žadatel povinen vyplnit formulář a tento výpis bude zajištěn prostřednictvím elektronické komunikace ERÚ s Rejstř́kem trestů) a odborná způsobilost nebo ustanovení odpovědného zástupce (kvalifikační préedpoklady nejsou třeba prokazovat pro zdroje o výkonu menším než 20 kW).

Finanční a technické předpoklady, které znamenají povinnost doložení vlastnického nebo užívacího práva k energetickému zařízení. Není-li žadatel vlastníkem energetického zařízení, je povinen doložit souhlas vlastníka energetického zařízení. Toto není povinen prokazovat žadatel o licenci na výrobu elektrriny, pokud bude instalovaný elektrický výkon výrobny elektřiny nižší než 200 kW. Energetické zařízení musí mít technickou úroveň odpovídající právním předpisům a technickým normám.

Energetický zákon ukládá držitelům licence na rozvod tepelné energie, kteří mají vhodné technické podmínky, povinnost vykupovat tepelnou energii získanou z OZE. Tato povinnost ovšem nevzniká, je-li potřeba tepelné energie již uspokojena z jiných zdrojů, pokud by došlo ke zvýšení celkových nákladů na pořízení tepelné energie pro soubor stávajících odběratelů či pokud parametry teplonosné látky neodpovídají parametrům v rozvodném tepelném zařízení v místě připojení.

Dne 30. května 2012 nabyla účinnosti novela Energetického zákona č. 165/2012 Sb, která se nazývá „O podporovaných zdrojích energie a o změně některých zákonů“. Tato novela přinesla změnu v oblasti zúčtování podpor z OZE a obchodování s energií z OZE, vytváří podmínky pro postupné zrušení podpory a uplatnění OZE na trhu bez podpory. Elektřinu vyrobenou OZE bude do konce roku 2012 povinně vykupovat provozovatel přenosové soustavy. Podpora elektřiny se stanoví do roku 2020. Novinkou je povinnost registrace. Do 30 dnů od udělení licence se výrobce energie s nárokem na podporu zaregistruje v centrálním systému operátora trhu (OTE, a.s.). Od ledna 2013 má výrobce energie možnost vybrat si mezi povinně vykupujícím obchodníkem a jiným obchodníkem. Podle toho si zvolí podporu zeleným bonusem nebo podporu výkupní ceny. Operátor trhu je pak povinen zelený bonus výrobci vyúčtovat. Česko je zavázáno do roku 2020 spotřebovávat 13,5 \% energie z OZE.

Pro stanovení minimálních výkupních cen energie z OZE zmocňuje Energetický zákon ERÚ. Vyhláška ERÚ č. 150/2007 Sb., o zpo̊sobu regulace cen v energetických odvětvích a postupech pro regulaci cen stanovuje vývoj výkupních cen v budoucnu. Tabulka č. 1 uvádí 
srovnání výkupních cen elektrické energie z obnovitelných zdrojů v ČR v letech 2007 - 2012. $\mathrm{V}$ tabulce jsou $\mathrm{V}$ př́ípadě rozmezí cen uváděna maxima (jedná se zejména o biomasu a bioplyn). Přes snížení výkupních cen FV energie, jsou pro fotovoltaiku stanoveny stále až 3 krát vyšší výkupní ceny než v případě jiných druhů OZE (VtE).

Tabulka č. 1: Srovnání výkupních cen elektrické energie z obnovitelných zdrojů v ČR. U fotovoltaiky je uvedena cena pro FVE s výkonem nad $100 \mathrm{~kW}(*)$. U fotovoltaiky pro rok 2012 je uvedena cena pro FVE s výkonem do $30 \mathrm{~kW}(* *)$.

SROVNÁNÍ VÝKUPNÍCH CEN ELEKTRICKÉ ENERGIE Z OBNOVITELNÝCH ZDROJŮ V ČR v CZK/kWh v letech 2007 - 2012

\begin{tabular}{|c|c|c|c|c|c|c|}
\hline ZDROJ/CENA & 2007 & 2008 & 2009 & 2010 & 2011 & 2012 \\
\hline FOTOVOLTAIKA $^{*}$ & 13,46 & 13,46 & 12,79 & 12,15 & 5,50 & $6,16 * *$ \\
\hline VĚTRNÉ ELEKTRÁRNY & 2,46 & 2,46 & 2,34 & 2,23 & 2,23 & 2,23 \\
\hline $\begin{array}{c}\text { MALÉ VODNÍ } \\
\text { ELEKTRÁRNY }\end{array}$ & 2,39 & 2,60 & 2,70 & 3,00 & 3,00 & 3,19 \\
\hline BIOMASA & 3,37 & 4,21 & 4,49 & 4,58 & 4,58 & 4,58 \\
\hline BIOPLYN Z BPS & 3,04 & 3,90 & 4,12 & 4,12 & 4,12 & 4,12 \\
\hline
\end{tabular}

Zdroj: Česká společnost pro větrnou energii [1].

Výkupní ceny a zelené bonusy jsou podle vyhlášky č. 140/2009 Sb. v platném znění uplatňovány po dobu životnosti výroben elektřiny. Doby garance výkupních cen pro jednotlivé druhy OZE nově uvedených do provozu po roku 2012 jsou uvedeny v tabulce č. 2.

Tabulka č. 2: Garance výkupních cen pro jednotlivé druhy OZE

\begin{tabular}{|c|c|}
\hline TYP OZE & GARANCE VÝKUPNÍCH CEN (LET) \\
\hline FOTOVOLTAICKÁ ELEKTRÁRNA & 20 \\
\hline VĚTRNÁ ELEKTRÁRNA & 20 \\
\hline MALÁ VODNÍ ELEKTRÁRNA & 30 \\
\hline BIOMASA & 20 \\
\hline BIOPLYN & 20 \\
\hline SKLÁDKOVÝ, KALOVÝ, DŮLNÍ PLYN & 15 \\
\hline GEOTERMÁLNÍ ELEKTRÁRNA & 20 \\
\hline
\end{tabular}

Zdroj: Energetický regulační úřad [5]. 


\section{Energie větru}

Největší větrný potenciál poskytují přímořské státy. I v České republice se nachází řada vhodný lokalit, které umožňují využít větrnou energii. K výstavbě větrné elektrárny je nezbytné získat územní rozhodnutí a následně stavební povolení podle zákona č. 183/2006 Sb., o územním plánování a stavebním řádu (,Stavební zákon“). Hlučnost provozu musí odpovídat hygienickým normám, podle vyhlášky Ministerstva zdravotnictví č. 13/1977 Sb., o ochraně zdraví před nepříznivými účinky hluku a vibrací. Některé podmínky jsou těžko splnitelné, zejména s přihlédnutím, že vhodné lokality pro stavbu větrných elektráren jsou ve vyšších nadmořských výškách. Potenciální místo by mělo být, pokud možno, bez výskytu nepříznivých meteorologických jevů, jako např. námraza. Stavba musí být rovněž v souladu se zákonem o civilním letectví, zákonem o ochraně přírody a krajiny. U větších staveb je nutné zajistit posouzení vlivů na životní prostředí (EIA) podle zákona č. 100/2001 Sb. o hodnocení vlivů na životní prostředí. U menších projektů probíhá postup formou oznámení záměru a sdělením stanoviska kraje. A samozrrejmě souhlas distributora elektrické energie $\mathrm{k}$ připojení na sít', podle Energetického zákona, bude-li elektřina dodávána do sítě.

\section{Energie vodních toků}

Dnes jsou v ČR možnosti využívat vodní energii v nových velkých vodních elektrárnách téměř vyčerpány. Takové stavby mají zásadní dopady na životní prostředí. Je však stále dost lokalit, vhodných pro využití vodního potenciálu v malé voní elektrárně. Malou vodní elektrárnou se rozumí, dle technické normy ČSN 73 6881, vodní elektrárna s instalovaným výkonem maximálně do $10 \mathrm{MW}$, včetně. Evropská unie pokládá za MVE vodní elektrárny do výkonu $5 \mathrm{MW}$. Většina výkonu vodních elektráren je z elektráren o výkonu větším než 5MW.

Obecné práva a povinnosti stanoví zákon č. 254/2001 Sb. o vodách a o změně některých zákonů (,Vodní zákon“). Opět je nutné získat stavební povolení dle Stavebního zákona a obvyklý požadavek EIA (opět dle velikosti a významu stavby). Podstoupit územní a vodoprávní řízení a získat stanovisko z hlediska územního plánu. U př́islušné správy povodí je nutné požádat o vydání povolení nakládání s vodami a souhlasu k využití vzdouvacího zařízení (jezu), pokud nejsme jeho vlastníky (zde se postupuje podle vyhlášky Ministerstva zemědělství č. 432/2001 Sb., § 8 Vodního zákona, Správního řádu). Zaevidovat se jako zájemce o stavbu malé vodní elektrárny na odboru životního prostředí příslušného úřadu státní správy. Dále je nutné opatřit si mapovou dokumentaci a snímky z pozemkové mapy na katastrálním úřadě, ověřit hydrologické podmínky lokality a zajistit vypracování technickoekonomické studie energetického využití lokality [3]. V provozu je nutné dodržovat podmínky stanovené vodoprávním úřadem $\mathrm{v}$ povolení $\mathrm{k}$ nakládání s vodami (dodržování odběru sjednaného množství vody a minimálního zůstatkového (sanačního) průtoku, zajištění odstraňování zachycených naplavenin, aj.).

\section{Tepelná energie zemského pláště, podzemních vod a energie prostředí}

Vysokopotenciální geotermální zdroje, umožňující využití geotermálního tepla nebo jako zdroje vytápění, se na území ČR našem území v podstatě nenacházejí. Je však možné využívat tzv. nízkopotenciální teplo za pomocí tepelného čerpadla. Prostřednictvím tohoto zařízení lze využívat tepelných rozdílů rozhraní země/voda, vzduch/voda, voda/voda, vzduch/vzduch.

Tuto problematiku normativně reguluje předně zákon č. 61/1988 Sb., o hornické činnosti, výbušninách a o státní báňské správě, vyhlášky Českého báňského úřadu, Zákon o vodách, 
EIA. Vrty pro tepelná čerpadla jsou zpravidla hlubší než $30 \mathrm{~m}$. Projekt na jejich provedení (obsahující geologickou a technickou část) musí vypracovat projektant s osvědčením báňského úrradu o odborné způsobilosti. Povolovací řízení, podobně jako $\mathrm{v}$ předchozích případech, se dělí na územní řízení o rozhodnutí o umístění stavby a na stavební řízení. $\mathrm{K}$ těmto správním řízením je nutné prezentovat dokumentace předepsané Stavebním zákonem, které nesmí být v rozporu s dokumentací báňského projektanta. Nutná autorizace projektanta záleží na tom, s čím systém pracuje (např. autorizace z oboru vodohospodářských staveb se požaduje u systému pracujícího s vodou, u nejběžnějších vrtů postačí autorizace pro pozemní stavby). Dalších autorizovaných osob je potřeba a to hydrogeologa (pro vydání vodoprávního souhlasu s vrtem pro tepelné čerpadlo) a inženýra (pro dokumentaci vrtu).

\section{Biomasa}

Biomasa je soubor látek tvořících těla organismů (rostlin i živočichů). Energie biomasy má svůj prapůvod ve slunečním záření a fotosyntéze, proto se jedná o obnovitelný zdroj energie. Ministerstvo životního prostředí k tomu vydalo vyhlášku 482/2005 Sb., o stanovení druhů, způsobů využití a parametrů biomasy při podpoře výroby elektrriny $\mathrm{z}$ biomasy, $\mathrm{k}$ provedení Zákona o podpoře OZE. Energie se získává především spalováním biomasy. Jde o nejstarší zdroj energie vůbec. Zásadní jsou plodiny a živočišné produkty s největší mírou výhřevnosti. Spalování biomasy se považuje za ekologické, nebot' $\mathrm{CO}_{2}$ uniklý do atmosféry by měl být pohlcen nově dorůstající biomasou.

\section{Sluneční energie}

Sluneční energie zastupuje naprostou majoritu energie, která se na Zemi nachází a využívá. Vzniká nukleárními reakcemi v nitru Slunce. Jako obnovitelný je tento zdroj energie nazván proto, že vyčerpání zásob vodíku na Slunci je očekáváno až v řádu miliard let. Množství energie, které získává zemský povrch ze slunečního záření, převyšuje přibližně $15.000 k$ rát současnou celosvětovou spotřebu energie [6].

Postup při zřizování fotovoltaické elektrárny je podobný jako u jiných OZE [8]. V prvé řadě je potřeba získat souhlas distributora elektrické energie k připojení na sít'. Nutný je také územní souhlas a stavební povolení stavebního úřadu, prostřednictvím Oznámení o záměru v území k vydání územního souhlasu (dle vyhlášky č. 503/2006 Sb. o podrobnějšší úpravě územního řízení, veřejnoprávní smlouvy a územního opatření). Z hlediska umístění fotovoltaického zařízení, mohou nastat $\mathrm{v}$ zásadě tři případy. Pokud je zařízení součástí technického vybavení nové stavby, podléhá režimu projednání povolované stavby. Zařízení může být instalované do stř̌ešního pláště, přičemž nedojde ke zvýšení ani rozšíření stavby, toto je možno považovat za stavební úpravu, která nevyžaduje, podle $\S 81$ odst. 3 písm. a) Stavebního zákona, územní rozhodnutí ani územní souhlas. V třetím případě se jedná o zařízení instalované na pozemku. Dle $\S 103$ odst. 1 písm. b) bod 4 Stavebního zákona je v tomto případě vyžadováno územní rozhodnutí nebo, za podmínek $§ 96$ Stavebního zákona, územní souhlas a stavební povolení. Stavební zákon v $§ 78$ odst. 3 a $§ 116$ odst. 1 umožňuje stavebníkovi uzavřít se stavebním úřadem veřejnoprávní smlouvu, která nahradí územní rozhodnutí ( 78 odst. 3) nebo stavební povolení (\$116 odst. 1). Dále je zde možnost uzavřít s autorizovaným inspektorem smlouvu o provedení kontroly projektové dokumentace pro stavbu, kterou hodlá provést a takovou stavbu již pouze oznámit stavebnímu úřadu (více $§ 117$ odst. 1).

Další nutností je získání kladného závazného stanoviska orgánu ochrany životního prostředí, dle zákona 114/1992 Sb., o ochraně př́rody a krajiny a nezbytné je také získání souhlasu s 
dočasným odnětím pozemku zemědělskému půdnímu fondu podle zákona č. 334/1992 Sb. o ochraně zemědělského půdního fondu, vyhlášky Ministerstva životního prostředí č. 13/1994 Sb. o upravení podrobností ochrany zemědělského půdního fondu a metodického pokynu $\mathrm{k}$ odnímání půdy ze zemědělského půdního fondu OOLP/1067/96. (Orgány ochrany životního prostředí trvají na dočasném odnětí celé plochy zasažené fotovoltaickými panely a to, i když půda pod těmito panely zůstane zemědělsky obdělavatelná) [9].

Z uvedeného vyplývá, že se realizační postup liší podle toho, zda majitel fotovoltaického zařízení využívá vyrobenou elektřinu pouze pro své účely, anebo je připojen k rozvodné síti. Pro druhý případ si shrňme nezbytné nejdůležitější kroky, které samozřejmě v prvém případě odpadají:

1. Získání stanoviska od jedné z energetických společností (ČEZ, PRE, E. ON).

2. Získání územního souhlasu, v závislosti na tom o jakou stavbu se jedná.

3. Získání licence ERÚ.

4. Uzavření smlouvy s distribuční společností.

5. Registrace účastníka trhu [9].

\section{Závěr}

Oblast OZE je z hlediska podnikání perspektivní hned z několika důvodů. V prvé řadě je zde jednoznačný přírodní potenciál i společenský a trend ke zvyšování podílu energie z OZE na celkové výrobě energie. Podle průzkumu veřejného mínění podporují OZE minimálně dvě třetiny obyvatel ČR. V druhé řadě je zde povinnost připojení a odběru energie z OZE-E a garance výkupních cen, což zaručuje návratnost větší počáteční investice a činí podnikání v oblasti podstatně méně rizikovým. Je sice celoevropským trendem zmenšovat a postupně rušit finanční podporu energie z OZE, přesto je využití této energie v zájmu ochrany klimatu a životního prostředí. Veškeré předpisy evropských společenství vychází v tomto duchu. Slunce, země, voda, vzduch, to jsou základní přírodní živly, které jsou lidem k dispozici už od počátku věků, a pravděpodobně tomu v budoucnu nebude jinak. Je zde stále potřeba se učit a objevovat možnosti jejich efektivního využívání a zároveň při tom respektovat př́rodu.

Podnikání v oblasti OZE však není pro každého. Není to klasické podnikání „buy/sell“ s jednoznačným výnosem. Na kolektor nedopadá svit slunce vždy stejně intenzivně, vítr nepohání vrtuli větrné elektrárny stejně rychle, a když dlouho neprší ani vodní elektrárna není schopna výroby energie. Podobně nestabilní jsou finanční a jiné podpory poskytované státem. Podnikatel by měl mít nejspíš vtah k životnímu prostředí a pustit se do této oblasti podnikání i $\mathrm{z}$ jiných důvodů než je vidina peněžního výnosu. Využívání energie z OZE patří k životnímu stylu moderního inteligentního člověka.

Zatímco zásoba fosilních paliv je omezená (ceny narůstají) a důvěra $\mathrm{v}$ jadernou energii je podlomena mj. katastrofou elektrárny Fukušima $\mathrm{v}$ Japonsku, energie ze slunce (jako významný původ většiny OZE) je prakticky nevyčerpatelná a s rostoucí účinností technologií přeměny $\mathrm{v}$ jiné formy energie (elektřinu, teplo), stoupá i význam těchto technologií $\mathrm{v}$ komerční sfére. Navíc je možné zaznamenat v poslední době pokles cen solárních panelů, čímž se zrychluje návratnost počáteční investice.

Předložený příspěvek sumarizuje právní podmínky pro využití OZE v ČR s důrazem na jednotlivé druhy OZE využitelné v klimatických podmínkách ČR. I přes zpřísnění podmínek a snížení atraktivity podnikání OZE v roce 2010, lze očekávat rozvoj této oblasti zejména ve stavebnictví - využití technologií OZE jako součásti technických zařízení budov (např. 
integrace FV technologií do střešní krytiny), kde je tato oblast velmi perspektivní a aktuální.

Poznámka: Příspěvek byl publikován za podpory Slezské univerzity v Opavě, grant IGS reg. číslo IGS/7/2012

\section{Literatura:}

[1] ČSVE: Srovnání výkupních cen elektrické energie z obnovitelných zdrojů v ČR. [online], $<$ http://www.csve.cz>, [2012-05-22]

[2] DAMOHORSKÝ, M. a kol.: Právo životního prostředí. 3. vydání. Praha: C. H. Beck, 2010, ISNB 978-80-7400-338-7

[3] Energetické konzultační středisko [on-line], <http://www.i-ekis.cz>, [2011-03-30]

[4] ENVIWEB: V solární technice přichází veškerá využitelná energie ze Slunce [on-line], $<$ http://www.enviweb.cz/clanek/fotovolt/67970/slunecni-energie>, [2011-02-04]

[5] ERÚ: FAQ - Obnovitelné zdroje energie, kombinovaná výroba elektřiny a tepla a druhotné zdroje [on-line], <www.eru.cz>, [2012-07-06]

[6] ERÚ: Podrobnosti $k$ udělení licence - Metodický návod Energetického regulačního úradu [on-line], č. 458/2000 Sb. <http://www.eru.cz/user_data/files/licence/ info_pro_zadatele/metod_pokyn_011_2009.pdf>, [2011-02-04]

[7] HOSPODÁŘSKÁ KOMORA ČR: Přriručka obnovitelné zdroje energie [on-line], $<$ http://www.businessinfo.cz/files/2005/061106_oborova-prirucka-oze.pdf>, [2011-0204]

[8] MMR: Metodická přiručka Ministerstva pro místní rozvoj k umístování, povolování a užívání fotovoltaických staveb a zařízení [on-line], <http://www.mmr.cz/ CMSPages/GetFile.aspx?guid=81a54c2f-8dff-4398-9de3-e9896996cba9>, [2011-02-05]

[9] OTE [on-line], <http://www.ote-cr.cz/>, [2011-03-24]

[10] Přehledný výčet právních předpisů [on-line]: <http://czepho.cz/cs/legislativa> [2011-0203]

[11]RE-SHAPING Project: Renewable Energy Policy Country profiles - 2011 version. [online], <http://www.reshaping-res-policy.eu>, [2012-07-06]

[12] SOPPEOVÁ, O.: Fotovoltaika ve vazbě na stavební zákon a předpisy související. $<\mathrm{http}: / /$ www.4-construction.com/cz/clanek/fotovoltaika-a-zakony/>, [2011-02-05]

\section{JEL K23, Q20, Q42, Q56}

\section{Mgr. Nina Pawliczková}

Advokátní koncipient

Luděk Václavek, Mgr., advokát

Václavská 316/12

12000 Praha 2

nmail@seznam.cz

\section{Ing. Adam Pawliczek, Ph.D.}

Odborný asistent KMP

Slezská univerzita v Opavě, Obchodně podnikatelská fakulta v Karviné

Univerzitní náměstí 1934/3

73340 Karviná

pawliczek@opf.slu.cz 